Global Conferences Series:

Social Sciences, Education and Humanities (GCSSSEH), Volume 3, 2019

The $1^{\text {st }}$ International Conference on Education, Social Sciences and Humanities

DOI: https://doi.org/10.326/hum0191

\title{
Evaluation of Implementation of Inclusive Education in West Sumatera
}

\section{Nurhastuti}

Universitas Negeri Padang

(*) $\square$ nurhastuti@fip.unp.ac.id

\begin{abstract}
The implementation of inclusive education in West Sumatera has been on 6 (six) years. In this period it has shown a fairly long journey. Therefore, the implementation of inclusive education in West Sumatera is comprehensively evaluated for the realization of the inclusive education goals. The evaluation process itself will be useful to see the inclusive values that have occurred in primary schools that serve students with special needs in West Sumatra. This research uses mixed method approach that is combination of qualitative and quantitative approach. The result of this research is the context component which covers the policy aspect of the program implementation, the program objectives and the context of its relation with the social culture of the society has not been fully implemented properly. The input components covering aspects of learners (students), educators (teachers), curriculum, infrastructure facilities, and financing the implementation of programs in inclusive schools have not been fully implemented properly. Process components that include aspects of learning planning activities, implementation of learning, and evaluation of learning and difficulties faced by teachers in teaching children with special needs in inclusive schools have not been fully implemented properly. Product components that include aspects of academic development of children with special needs and aspects of social skills development of students in inclusive schools can be said to have been implemented properly.
\end{abstract}

Keyword: Evaluation, Implementation, Inclusive Education In West Sumatera

\section{Introduction}

Inclusive education is an approach that seeks to transform the educational system by eliminating barriers that can prevent every student from participating fully in education.

Copyright (C) 2019, the Authors. Published by Redwhite Press.

Page | 17

This is an open access article under the CC BY-NC license

(http://creativecommons.org/licenses/by-nc/4.0). 
In other words, inclusive education is the educational service of children with special needs who are educated together with other children (normal) to optimize their potential. The importance of inclusive education is that education is a basic human right, and inclusive education is also a good education and can foster a sense of social well-being.

Increasing attention to inclusive education from many groups, especially education providers, does not automatically run smoothly. However, various views and attitudes can in fact hinder the implementation of inclusive education more diverse. At the level of practice in the field, the implementation of inclusive education encounters various obstacles and challenges. Frequently reported constraints are misconceptions about the inconsistent concepts of inclusive education, inconsistent regulations or policies, an education system that is not flexible and so on.

It is believed that the implementation of inclusive education is a challenge that is not easy to put into practice in school life. There is no magic, efficacious, special or science education that is "magical" in integrating children with special needs into public schools. The movement toward inclusive education in schools is both seen in theory and in practice requires change. Initially, inclusive education requires different learning formats, different methods, in grouping children and in different learning activities. Even when making learning plans, the results to be achieved were made different. In addition, the leadership of the principal, including his commitment to receive special needs children in school is still a problem. Even the views of the surrounding community on inclusive education can not yet be said to fully support the creation of inclusive education.

Particularly in West Sumatra, the seriousness of the Provincial Government in the implementation of the inclusive education program is marked by the establishment of Special Education and Special Services in the Education Office. In addition, the Provincial Government also built schools that also held inclusive education. The West Sumatera Provincial Government continues to promote and improve the equitable quality of education, providing access to an increasingly open education for the people of West Sumatra, including the poor. Also, it is determined that in 2015 there will be no more school-aged children who are not in school, not to mention children with special needs.

The implementation of inclusive education in West Sumatera has been on 6 (six) years. In this period of time it has shown a fairly long journey. Therefore, the implementation of inclusive education in West Sumatra should be comprehensively evaluated for the realization of the ideals of inclusive education. The evaluation process itself will be useful to see the inclusive values that have occurred in Primary Schools that serve students with special needs in West Sumatra.

Based on the above phenomenon, in this study formulated research problems as follows:

1. What is the context component of inclusive education covering the policy aspects of program implementation, program objectives and the context of its relation to sociocultural society?

2. What is the input components of inclusive education covering aspects of learners (students), educators (teachers), curriculum, infrastructure facilities, and financing the implementation of programs in inclusive schools?

3. What is the component of the process of inclusive education which includes aspects of learning planning activities, implementation of learning, and evaluation of learning 
and difficulties faced by teachers in teaching children with special needs in inclusive schools?

4. What is the components of inclusive education products covering aspects of the academic development of children with special needs and aspects of social skills development of students in inclusive schools?

\section{Method}

In this research, researcher use mix method approach that is combination of qualitative approach with quantitative. In this study, the authors used a quantitative approach to process the data obtained from the research location, where the quantitative data is obtained through secondary data. This research will be conducted in 3 regencies / cities in West Sumatera, namely Padang, Bukttinggi and Payakumbuh. Each region has 3 Elementary Schools that have implemented an inclusive education system. The research variables in this study can be seen in the table below.

Table 1 Research Instrument Grid

\begin{tabular}{|c|c|c|}
\hline Variabel & Dimensi & Indikator \\
\hline (1) & (2) & (3) \\
\hline \multirow[t]{4}{*}{$\begin{array}{l}\text { Evaluation of } \\
\text { Implementation of } \\
\text { Inclusive Education in } \\
\text { West Sumatra }\end{array}$} & $\begin{array}{l}\text { Context Component of the } \\
\text { Implementation of } \\
\text { Inclusive Education }\end{array}$ & $\begin{array}{l}\text { 1. Program } \\
\text { implementation } \\
\text { policies } \\
\text { 2. Program objectives } \\
\text { 3. The context of its } \\
\text { relationship with the } \\
\text { social culture of the } \\
\text { community }\end{array}$ \\
\hline & $\begin{array}{l}\text { Input Component of the } \\
\text { Implementation of } \\
\text { Inclusive Education }\end{array}$ & $\begin{array}{l}\text { 1. Learners (students) } \\
\text { 2. Educators (teachers) } \\
\text { 3. Curriculum } \\
\text { 4. Facilities } \\
\text { infrastructure } \\
\text { 5. Financing the } \\
\text { implementation of } \\
\text { programs in inclusive } \\
\text { schools }\end{array}$ \\
\hline & $\begin{array}{l}\text { Process Component of the } \\
\text { Implementation of } \\
\text { Inclusive Education }\end{array}$ & $\begin{array}{l}\text { 1. Learning planning } \\
\text { activities } \\
\text { 2. Implementation of } \\
\text { learning } \\
\text { 3. Evaluation of learning } \\
\text { 4. Difficulties faced by } \\
\text { teachers in teaching } \\
\text { children with special } \\
\text { needs in inclusive } \\
\text { schools }\end{array}$ \\
\hline & Product Component of the & 1. Results of academic \\
\hline
\end{tabular}




\begin{tabular}{ll}
\hline Implementation of & $\begin{array}{l}\text { development of } \\
\text { Inclusive Education }\end{array}$ \\
& $\begin{array}{l}\text { children with special } \\
\text { needs }\end{array}$ \\
& $\begin{array}{l}\text { Development of social } \\
\text { skills of students in } \\
\text { inclusive schools }\end{array}$ \\
\hline
\end{tabular}

Data collection techniques used in this study are questionnaires, interviews, observation and literature study. The data has been collected for easy analysis and concluded then the authors use the analysis that produces descriptive analysis. This research is an evaluation study trying to compare the implementation of inclusion education in the field with certain criteria or standard that should be. The criteria are qualitative criteria. The things considered in determining the qualitative criteria are the indicators in the component of the object under study, ie the constituent indicators of the implementation of inclusive education (Arikunto, 2010). The process of data analysis using inductive thinking that is the process of data processing of the things that are specific and obtained from the respondents then draw conclusions in general.

\section{Results and Discussion}

Context Component of the Implementation of Inclusive Education

In the context component of the determination of the success criteria of inclusive education in this study can be seen from the results of questionnaires spread on 9 Principals and 18 teachers as follows.

Table 2 Respondents' Response to Context Component the Implementation of Inclusive Education

\begin{tabular}{|c|c|c|c|c|c|c|c|c|c|c|c|c|c|}
\hline \multirow[t]{3}{*}{ No. } & \multirow[t]{3}{*}{ Statement } & \multicolumn{10}{|c|}{ Answer Score } & \multirow{2}{*}{\multicolumn{2}{|c|}{$\begin{array}{l}\text { Total } \\
\text { Score }\end{array}$}} \\
\hline & & \multicolumn{2}{|c|}{5} & \multicolumn{2}{|c|}{4} & \multicolumn{2}{|c|}{3} & \multicolumn{2}{|r|}{2} & \multicolumn{2}{|c|}{1} & & \\
\hline & & $\mathbf{F}$ & $\%$ & $\mathbf{F}$ & $\%$ & F & $\%$ & $\mathbf{F}$ & $\%$ & $\mathbf{F}$ & $\%$ & $\mathbf{F}$ & $\%$ \\
\hline 1. & $\begin{array}{l}\text { Local } \\
\text { governments } \\
\text { support inclusive } \\
\text { education } \\
\text { programs. }\end{array}$ & 5 & 18,5 & 22 & 81,5 & - & - & - & - & - & - & 27 & 100 \\
\hline 2. & $\begin{array}{l}\text { There is the } \\
\text { assistance of } \\
\text { special } \\
\text { counselors by the } \\
\text { government. }\end{array}$ & - & - & - & - & 9 & 33,3 & 18 & 66,7 & - & - & 27 & 100 \\
\hline 3. & $\begin{array}{l}\text { There are } \\
\text { socialization } \\
\text { activities and } \\
\text { policy } \\
\text { coordination. }\end{array}$ & - & - & 2 & 7,4 & 6 & 22.2 & 19 & 70,4 & - & - & 27 & 100 \\
\hline 4. & $\begin{array}{l}\text { There is guidance } \\
\text { and supervision }\end{array}$ & 1 & 3,7 & 4 & 14,8 & 21 & 77,8 & 1 & 3,7 & - & - & 27 & 100 \\
\hline
\end{tabular}




\begin{tabular}{|c|c|c|c|c|c|c|c|c|c|c|c|c|c|}
\hline \multirow[t]{3}{*}{ No. } & \multirow[t]{3}{*}{ Statement } & \multicolumn{10}{|c|}{ Answer Score } & \multirow{2}{*}{\multicolumn{2}{|c|}{$\begin{array}{l}\text { Total } \\
\text { Score }\end{array}$}} \\
\hline & & \multicolumn{2}{|r|}{5} & \multicolumn{2}{|c|}{4} & \multicolumn{2}{|c|}{3} & \multicolumn{2}{|c|}{2} & \multicolumn{2}{|c|}{$\overline{1}$} & & \\
\hline & & $F$ & $\%$ & $F$ & $\%$ & $F$ & $\%$ & $F$ & $\%$ & $\mathbf{F}$ & $\%$ & $F$ & $\%$ \\
\hline & $\begin{array}{l}\text { in the } \\
\text { implementation } \\
\text { of inclusive } \\
\text { education. }\end{array}$ & & & & & & & & & & & & \\
\hline 5. & $\begin{array}{l}\text { Schools use } \\
\text { flexible } \\
\text { curriculum. }\end{array}$ & 3 & 11,1 & 22 & 81,5 & 2 & 7,4 & - & - & - & - & 27 & 100 \\
\hline 6. & $\begin{array}{l}\text { School has been } \\
\text { accredited A. }\end{array}$ & 4 & 14,8 & 23 & 85,2 & - & - & - & - & - & - & 27 & 100 \\
\hline 7. & $\begin{array}{l}\text { There is an } \\
\text { evaluation of the } \\
\text { implementation } \\
\text { of inclusive } \\
\text { education. }\end{array}$ & - & - & - & - & 7 & 25,9 & 19 & 70,4 & 1 & 3,7 & 27 & 100 \\
\hline 8. & $\begin{array}{l}\text { Supported by } \\
\text { human resources } \\
\text { involved in } \\
\text { organizing } \\
\text { inclusion in } \\
\text { schools. }\end{array}$ & 1 & 3,7 & 1 & 3,7 & 5 & 18,5 & 20 & 74,1 & - & - & 27 & 100 \\
\hline 9. & $\begin{array}{l}\text { School land to } \\
\text { provide adequate } \\
\text { dedicated space. }\end{array}$ & - & - & 3 & 11,1 & 7 & 25,9 & 17 & 63,0 & - & - & 27 & 100 \\
\hline 10. & $\begin{array}{l}\text { There are many } \\
\text { parents who } \\
\text { enroll their } \\
\text { children who } \\
\text { have special } \\
\text { needs in the } \\
\text { school. }\end{array}$ & 8 & 29,6 & 19 & 70,4 & - & - & - & - & - & - & 27 & 100 \\
\hline & Total & 22 & & 96 & & 57 & & 94 & & 1 & & 270 & \\
\hline & Total x Score & & 10 & & 84 & & 71 & & 88 & & 1 & & \\
\hline & Ideal Score & & & & & & 1.3 & & & & & & \\
\hline & P (\%) & & & & & & 63 & & & & & & \\
\hline
\end{tabular}

Based on the above table it can be explained that the total score of total responses of respondents to the indicator context component of the implementation of inclusive education is $63.3 \%$. The total score of respondents is categorized fairly well. Input Component of the Implementation of Inclusive Education 
On the input component of determining the success criteria of inclusive education in this study can be seen from the results of questionnaires spread on 9 Principals and 18 teachers as follows.

Table 3. Respondents' Response to Input Component the Implementation of Inclusive Education

\begin{tabular}{|c|c|c|c|c|c|c|c|c|c|c|c|c|c|}
\hline \multirow[t]{3}{*}{ No. } & \multirow{3}{*}{ Statement } & \multicolumn{10}{|c|}{ Answer Score } & \multirow{2}{*}{\multicolumn{2}{|c|}{$\begin{array}{l}\text { Total } \\
\text { Score }\end{array}$}} \\
\hline & & \multicolumn{2}{|c|}{5} & \multicolumn{2}{|c|}{4} & \multicolumn{2}{|c|}{3} & \multicolumn{2}{|c|}{2} & \multicolumn{2}{|c|}{1} & & \\
\hline & & $F$ & $\%$ & $\mathbf{F}$ & $\%$ & $\mathbf{F}$ & $\%$ & $F$ & $\%$ & $F$ & $\%$ & $F$ & $\%$ \\
\hline 1. & $\begin{array}{l}\text { The process of } \\
\text { admission of } \\
\text { new students to } \\
\text { children with } \\
\text { special needs is } \\
\text { treated } \\
\text { similarly with } \\
\text { other children. }\end{array}$ & 6 & 22,2 & 19 & 70,4 & 2 & 7,4 & - & - & - & - & 27 & 100 \\
\hline 2. & $\begin{array}{l}\text { In the reception } \\
\text { of students } \\
\text { with special } \\
\text { needs used } \\
\text { equipment and } \\
\text { special } \\
\text { knowledge. }\end{array}$ & - & - & 4 & 14,8 & 8 & 29,6 & 15 & 55,6 & - & - & 27 & 100 \\
\hline
\end{tabular}

3. Teachers have $\quad \begin{array}{llllllllllllll} & 9 & 33,3 & 15 & 55,6 & 3 & 11,1 & - & - & - & - & 27 & 100\end{array}$ the ability to

organize

teaching and

learning

process in the

implementation

of inclusive

education

program.

4. Teachers have

special

educational

background

and

extraordinary

education.

5. Schools have $\quad \begin{array}{llllllllllll}6 & 22,2 & 17 & 63,0 & 3 & 11,1 & 1 & 3,7 & - & - & 27 & 100\end{array}$ made

curriculum

modifications

(KTSP) and

other learning 


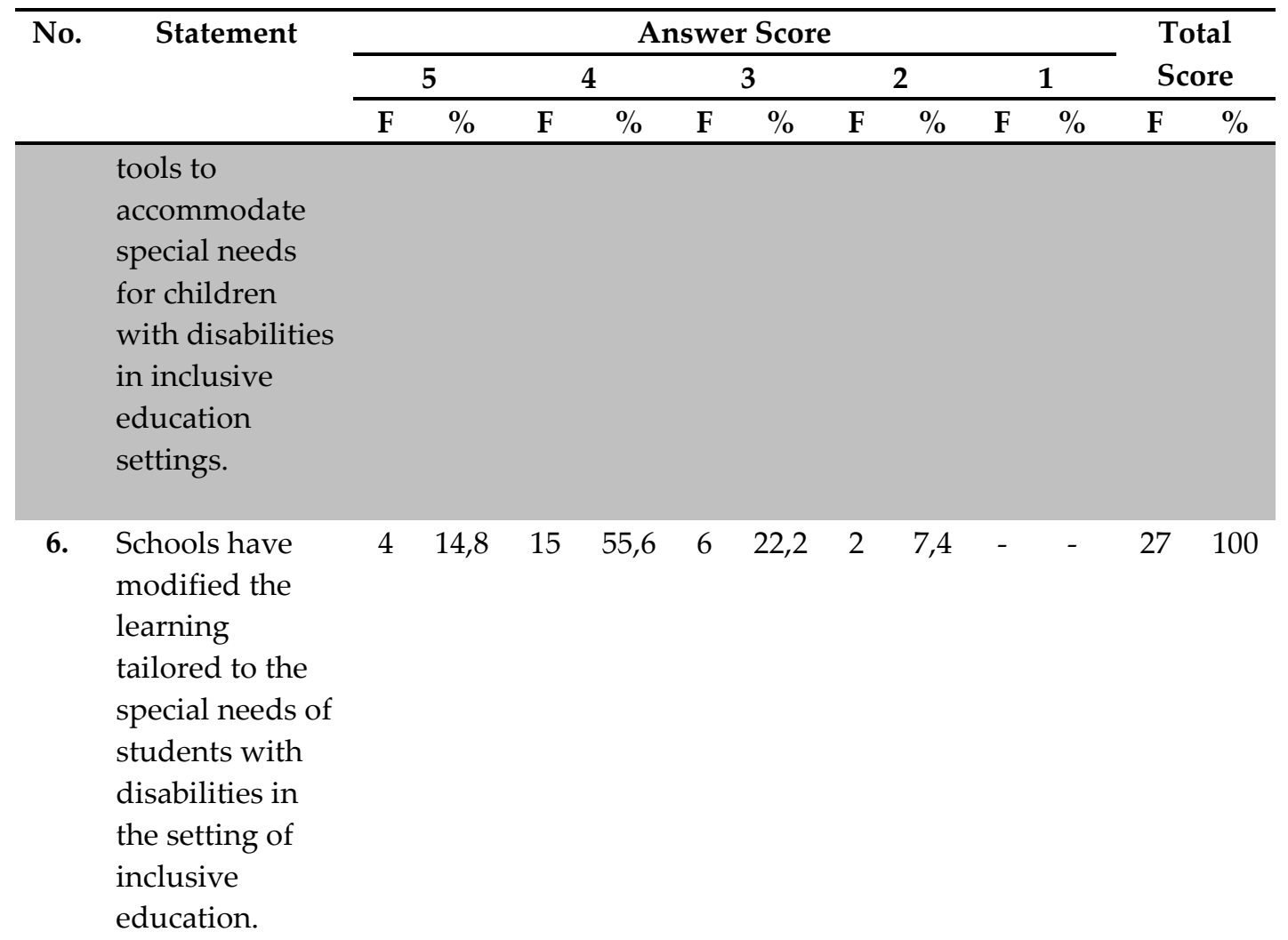

7. Schools have $\quad \begin{array}{llllllllllll}6 & 22,2 & 12 & 44,4 & 5 & 18,5 & 4 & 14,8 & - & - & 27 & 100\end{array}$ adequate

facilities and

infrastructure

in the

implementation

of teaching and

learning

activities in the

setting of

inclusive

education.

8. Schools have $\quad \begin{array}{llllllllllll} & 1 & 3,7 & 6 & 22,2 & - & - & 20 & 74,1 & - & - & 27\end{array}$

special learning

tools and tools,

or special

instructional

media based on

the type of

abilities

students with

special needs

that exist. 


\begin{tabular}{|c|c|c|c|c|c|c|c|c|c|c|c|c|c|}
\hline \multirow[t]{3}{*}{ No. } & \multirow[t]{3}{*}{ Statement } & \multicolumn{10}{|c|}{ Answer Score } & \multirow{2}{*}{\multicolumn{2}{|c|}{$\begin{array}{l}\text { Total } \\
\text { Score }\end{array}$}} \\
\hline & & \multicolumn{2}{|r|}{5} & \multicolumn{2}{|c|}{4} & \multicolumn{2}{|c|}{3} & \multicolumn{2}{|c|}{2} & \multicolumn{2}{|c|}{1} & & \\
\hline & & $\mathbf{F}$ & $\%$ & $\mathbf{F}$ & $\%$ & $\mathbf{F}$ & $\%$ & $\mathbf{F}$ & $\%$ & $\mathbf{F}$ & $\%$ & $\mathbf{F}$ & $\%$ \\
\hline 9. & $\begin{array}{l}\text { Schools have } \\
\text { sufficient funds } \\
\text { in the } \\
\text { implementation } \\
\text { of inclusive } \\
\text { education } \\
\text { programs. }\end{array}$ & 8 & 29,6 & 9 & 33,3 & 8 & 29,6 & 2 & 7,4 & - & - & 27 & 100 \\
\hline 10. & $\begin{array}{l}\text { Governments } \\
\text { and } \\
\text { communities } \\
\text { help to provide } \\
\text { funding for } \\
\text { inclusive } \\
\text { schools. }\end{array}$ & 11 & 40,7 & 16 & 59,3 & - & - & - & - & - & - & 27 & 100 \\
\hline & Total & 51 & & 113 & & 35 & & 68 & & 3 & & 270 & \\
\hline & Total x Score & & 55 & & 52 & & 05 & & 36 & & 3 & & \\
\hline & Ideal Score & & & & & & 1.3 & & & & & & \\
\hline & $P(\%)$ & & & & & & & & & & & & \\
\hline
\end{tabular}

Based on the above table it can be explained that the total score of total responses of respondents to the indicator input component of the implementation of inclusive education is $70.4 \%$. The total score of respondents is categorized fairly well.

Process Component of the Implementation of Inclusive Education

On the process component of determining the success criteria of inclusive education in this study can be seen from the results of questionnaires spread on 9 Principals and 18 teachers as follows.

Table 4. Respondents' Response to Process Component the Implementation of Inclusive Education

\begin{tabular}{|c|c|c|c|c|c|c|c|c|c|c|c|c|c|}
\hline \multirow[t]{3}{*}{ No. } & \multirow[t]{3}{*}{ Statement } & \multicolumn{10}{|c|}{ Answer Score } & \multirow{2}{*}{\multicolumn{2}{|c|}{$\begin{array}{l}\text { Total } \\
\text { Score }\end{array}$}} \\
\hline & & \multicolumn{2}{|c|}{5} & \multicolumn{2}{|r|}{4} & \multicolumn{2}{|c|}{3} & \multicolumn{2}{|r|}{2} & \multicolumn{2}{|c|}{1} & & \\
\hline & & $\mathbf{F}$ & $\%$ & $\mathbf{F}$ & $\%$ & $F$ & $\%$ & $\mathbf{F}$ & $\%$ & $F$ & $\%$ & $\mathbf{F}$ & $\%$ \\
\hline 1. & $\begin{array}{l}\text { Personal } \\
\text { organizers of } \\
\text { inclusive } \\
\text { education } \\
\text { programs plan } \\
\text { well with learning } \\
\text { activities in } \\
\text { inclusive } \\
\text { education } \\
\text { programs. }\end{array}$ & 5 & 18,5 & 19 & 70,4 & 3 & 11,1 & - & - & - & - & 27 & 100 \\
\hline 2. & $\begin{array}{l}\text { Personal } \\
\text { organizers of }\end{array}$ & - & - & 4 & 14,8 & 5 & 18,5 & 18 & 66,7 & - & - & 27 & 100 \\
\hline
\end{tabular}




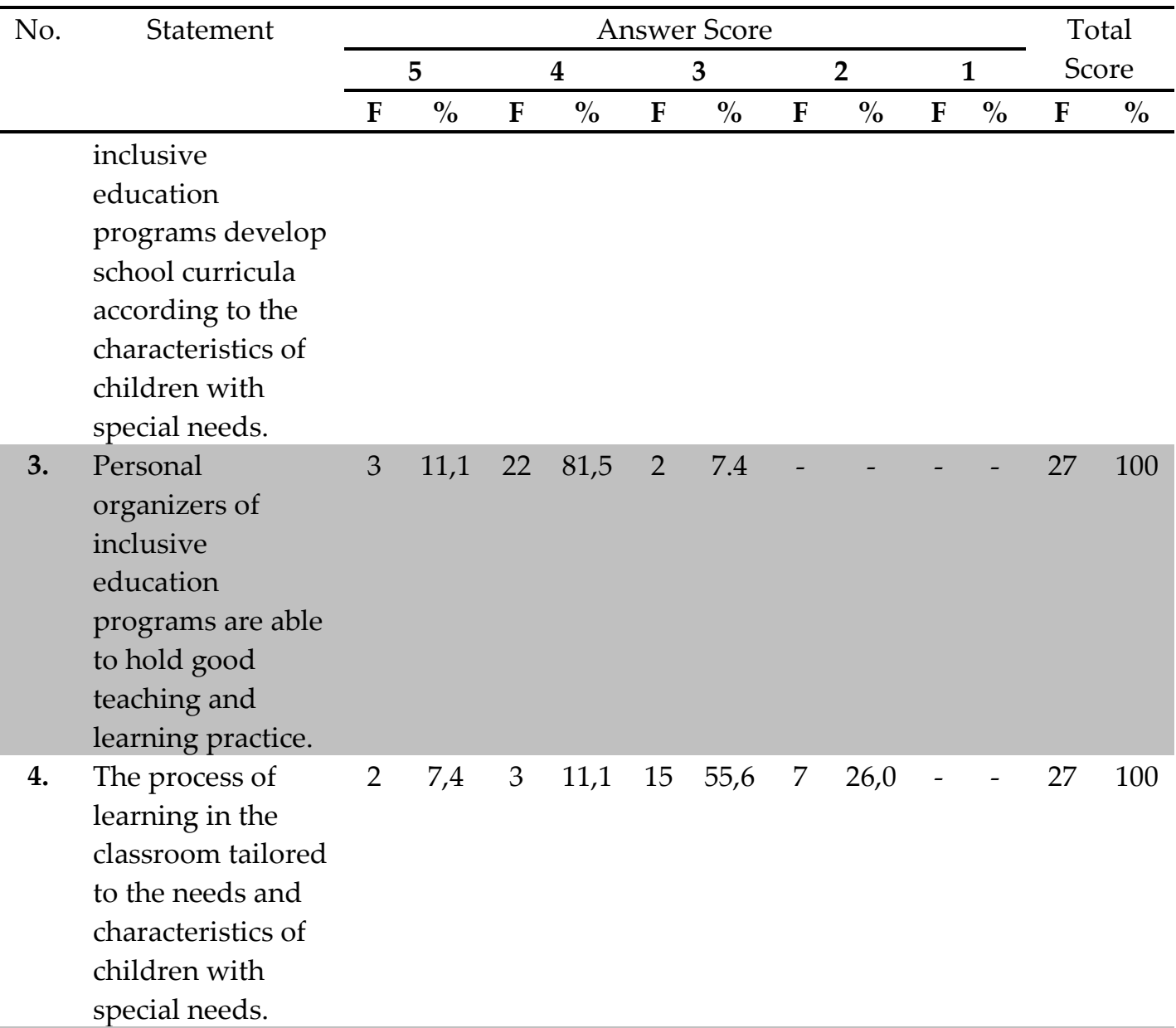

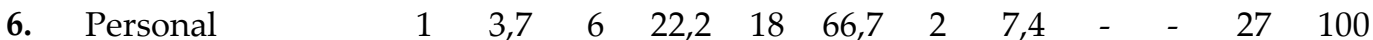

organizers of

inclusive

education

programs carry

out learning

evaluations to

learners using

different

graduation

standards.

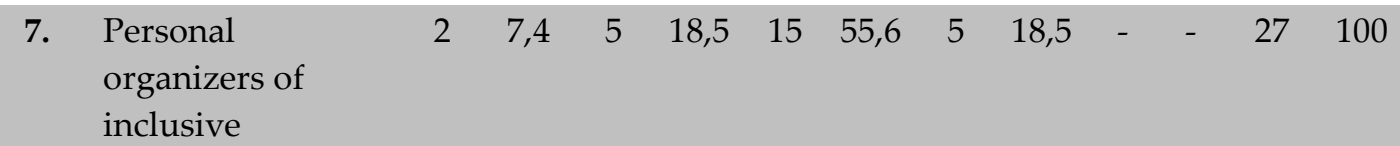




\begin{tabular}{|c|c|c|c|c|c|c|c|c|c|c|c|c|c|}
\hline \multirow[t]{3}{*}{ No. } & \multirow[t]{3}{*}{ Statement } & \multicolumn{10}{|c|}{ Answer Score } & \multirow{2}{*}{\multicolumn{2}{|c|}{$\begin{array}{l}\text { Total } \\
\text { Score }\end{array}$}} \\
\hline & & \multicolumn{2}{|c|}{5} & \multicolumn{2}{|c|}{4} & \multicolumn{2}{|r|}{3} & \multicolumn{2}{|r|}{2} & \multicolumn{2}{|c|}{1} & & \\
\hline & & $\mathbf{F}$ & $\%$ & $\mathbf{F}$ & $\%$ & $\mathbf{F}$ & $\%$ & $\mathbf{F}$ & $\%$ & $\mathbf{F}$ & $\%$ & $\mathbf{F}$ & $\%$ \\
\hline & $\begin{array}{l}\text { education } \\
\text { programs are able } \\
\text { to arrange the } \\
\text { RPP well. }\end{array}$ & & & & & & & & & & & & \\
\hline 8. & $\begin{array}{l}\text { Teacher delivered } \\
\text { the learning } \\
\text { materials well. }\end{array}$ & 3 & 11,1 & 2 & 7,4 & 7 & 26,0 & 15 & 55,6 & - & - & 27 & 100 \\
\hline & Total & 28 & & 76 & & 65 & & 47 & & - & - & 216 & \\
\hline & Total x Score & & 40 & & 4 & & 95 & & 94 & & - & & 33 \\
\hline & Ideal Score & & & & & & 1.0 & & & & & & \\
\hline & $\mathrm{P}(\%)$ & & & & & & 67 & & & & & & \\
\hline
\end{tabular}

Based on the above table it can be explained that the total score of total responses of respondents to the indicator process component of the implementation of inclusive education is $67.9 \%$. The total score of respondents is categorized fairly well.

\section{Product Component of the Implementation of Inclusive Education}

On the product component of determining the success criteria of inclusive education in this study can be seen from the results of questionnaires spread on 9 Principals and 18 teachers as follows.

Table 5. Respondents' Response to Product Component the Implementation of Inclusive Education

\begin{tabular}{|c|c|c|c|c|c|c|c|c|c|c|c|c|c|}
\hline \multirow[t]{3}{*}{ No. } & \multirow[t]{3}{*}{ Statement } & \multicolumn{10}{|c|}{ Answer Score } & \multirow{2}{*}{\multicolumn{2}{|c|}{$\begin{array}{l}\text { Total } \\
\text { Score }\end{array}$}} \\
\hline & & \multicolumn{2}{|c|}{5} & \multicolumn{2}{|c|}{4} & \multicolumn{2}{|c|}{3} & \multicolumn{2}{|c|}{2} & \multicolumn{2}{|c|}{1} & & \\
\hline & & $\mathbf{F}$ & $\%$ & $\mathbf{F}$ & $\%$ & $\mathbf{F}$ & $\%$ & $\mathbf{F}$ & $\%$ & $\mathbf{F}$ & $\%$ & $\mathbf{F}$ & $\%$ \\
\hline 1. & $\begin{array}{l}\text { Children with } \\
\text { special needs who } \\
\text { take the exam can be } \\
\text { passed entirely. }\end{array}$ & 11 & 40,7 & 16 & 59,3 & - & - & - & - & - & - & 27 & 100 \\
\hline 2. & $\begin{array}{l}\text { This school } \\
\text { produces students } \\
\text { with special needs } \\
\text { who are able to } \\
\text { continue their } \\
\text { studies to school at a } \\
\text { higher level. }\end{array}$ & 7 & 26,0 & 18 & 66,7 & 2 & 7,4 & - & - & - & - & 27 & 100 \\
\hline 3. & $\begin{array}{l}\text { Children with } \\
\text { special needs can } \\
\text { mingle with their } \\
\text { friends at school. }\end{array}$ & 21 & 77,8 & 6 & 22,2 & - & - & - & - & - & - & 27 & 100 \\
\hline 4. & $\begin{array}{l}\text { Normal students can } \\
\text { accept the presence } \\
\text { of students with }\end{array}$ & 10 & 37,0 & 15 & 55,6 & 2 & 7,4 & - & - & - & - & 27 & 100 \\
\hline
\end{tabular}


special needs in the

classroom to carry

out teaching and

learning activities

together.

\begin{tabular}{|c|c|c|c|c|c|c|}
\hline Total & 49 & 55 & 4 & - & - & 108 \\
\hline Total x Skor & 245 & 220 & 12 & - & - & 477 \\
\hline Skor Ideal & \multicolumn{6}{|c|}{540} \\
\hline P (\%) & \multicolumn{6}{|c|}{88,3} \\
\hline
\end{tabular}

Based on the above table it can be explained that the total score of total responses of respondents to the indicator process component of the implementation of inclusive education is $67.9 \%$. The total score of respondents is categorized very good.

\section{Discussion}

Context Component of the Implementation of Inclusive Education

The results of the indicators of the context component of the implementation of inclusive education can be explained from the following aspects:

1. The existence of legislation policy as a formal basis clearly stated and firmly.

2. The purpose of implementing a clear and focused inclusive education program.

3. The existence of socio-cultural conditions of society that support the implementation of inclusive education programs.

Input Component of the Implementation of Inclusive Education

The results of the indicators of the input component of the implementation of inclusive education can be explained from the following aspects:

1. The presence of students with special needs.

2. The presence of an adequate teacher.

3. The existence of a curriculum that is adapted to the needs and characteristics of children with special needs.

4. The existence of sufficient budget provision that comes from the government and society.

Process Component of the Implementation of Inclusive Education

The results of the indicators of the process component of the implementation of inclusive education can be explained from the following aspects:

1. Learning planning activities.

2. Implementation of learning.

3. Evaluation of learning.

4. Difficulties faced by teachers in teaching children with special needs in inclusive schools.

Product Component of the Implementation of Inclusive Education

The results of the indicators of the product component of the implementation of inclusive education can be explained from the following aspects:

1. Aspects of academic development of children with special needs.

2. Aspects of social skills development of students in inclusive schools. 


\section{Conclusion}

Components context: policy and legal basis for the implementation of inclusive education have not fully met the criteria seen from the unseen and clearly and firmly found in the Education System Act in our country. The context of the objectives of the implementation of inclusive education is in accordance with national education objectives and has met the criteria; this is seen from the basic goals of national education and the goal of inclusive education equally intellectual life of the nation. While the sociocultural context of society in the implementation of inclusive education has met the criteria seen from the implementation of inclusive education that is in line with the philosophy of our society is Bhineka Tunggal Ika.

Input component: the admission of new students with special needs has met the criteria, this is seen from the number of children with special needs when enrolled in the same with normal children. Input identification of children with special needs when registering has not fully meet the criteria seen from the teacher just do the observation by looking at the physical types of abnormalities of children with special needs. Input of the number of children with special needs who attend school has not fully met the criteria seen from the number of percentage of children with special needs large enough from the ideal amount. Input types of children with special needs have met the criteria seen from the type of abnormalities of children with special needs are very diverse. Input attitude of normal students have met the criteria seen from the questionnaire results that show all normal students to be positive to children with special needs. The Input teachers have met the criteria seen from most of the number of teachers already Bachelor (S1) and civil servant status. Input the number of teachers with special needs children have not fully meet the criteria seen still small percentage of general teachers as teachers with special needs children. The curriculum input has met the criteria seen in the curriculum model used by the school of special organizers for children with special needs. Input of public facilities is considered sufficient while the input of special facilities for children with special needs is considered inadequate and has not fully meet the criteria seen from the special facilities that most of them are not owned by the school. Input financing of program implementation has not fully met the criteria seen from the type and source of assistance it provides. While the attitude of parents of students have met the criteria seen from the questionnaire that all parents have a positive attitude towards the implementation of inclusive programs.

Components of the process of assessment of planning activities, implementation and evaluation of learning in general have met the criteria seen from the score that entered the category good and quite good. The process of difficulty faced by teachers in the planning of learning as in the aspect of pouring the indicators to be subject matter that must be tailored to children with special needs and prepare the material / material and plan the source of learning has not fully meet the criteria seen from the school still use the regular curriculum that is applied equally to the whole students. The process of difficulty faced by teachers in the implementation of learning as in the aspects of presenting the subject matter and using learning resources and tools / learning media has not fully meet the criteria seen from the condition of children with special needs are weak in absorbing the subject matter so that should be explained and demonstrated by teachers repeatedly. While the process of difficulties faced by teachers in the evaluation of learning in the aspect of providing assessment of student learning outcomes of children with special 
needs has not fully meet the criteria seen condition characteristics of children with special needs different from normal students.

Product Components: the development of achievement level of academic learning of children with special needs has met the criteria seen from the acquisition of UAS and UN results that show the results are quite encouraging and included in the category good and good enough. While the product of social aspects of student development shows a very good development and meets the criteria seen from the attitude of all normal students who want to accept the existence of children with special needs in school.

\section{References}

Arikunto, Suharsimi. 2010. Prosedur Penelitian: Suatu Pendekatan Praktek. Jakarta: Rineka Cipta.

Abdulrahman, Mulyono. 2003. Landasan Pendidikan Inklusif dan Implikasinya dalam Penyelenggaraan LPTK.Makalah disajikan dalam pelatihan penulisan buku ajar bagi dosen jurusan PLB yang diselenggarakan oleh Ditjen Dikti. Yogyakarta, 26 Agustus 2002.

Ainscow, M and Booth, T. 2002. Index for Inclusion Developing Learning and Participation in Schools. Hobboken: CSIE Mark Vaughan.

Burgwin, Elizabeth. 1996. Special Needs Education. London: Kogan Page.

Calberg, C. \& K. Kavale. 1980. The efficacy of Special Class vs Regular Class Placement for Exceptional Children: A Metaaanalysis. The Journal of Special Education Vol 14.

Delphie, B. 2006. Pembelajaran Anak Berkebutuhan Khusus dalam Setting Pendidikan Inklusif. Bandung: Refika Aditama.

Departemen Pendidikan Nasional. 2003. Kebijakan Pemerintah Dalam Pendidikan Inklusif. Jakarta: Departemen Pendidikan Nasional.

Direktorat PLB. 2007. Pedoman Khusus Penyelenggaraan Pendidikan Inklusif, Manajemen Sekolah Penyelenggara Pendidikan Inklusif. Jakarta: Direktorat Pembinaan Sekolah Luar Biasa.

Heller, Holtzman \& Messick. The National Academy of Sciences. Amerika: Special Education Publishing, 1982.

Johnsen, Berit H. dan Skjorten, Miriam D. Pendidikan Kebutuhan Khusus: Sebuah Pengantar, Bandung: Program Pascasarjana Universitas Pendidikan Indonesia. 2003.

Sugiyono. 2010. Metode Penelitian Bisnis. Cetakan Kedelapan. Bandung: Alfabeta.

Stubbs, Sue. 2002. Pendidikan Inklusif: Ketika Hanya Sedikit Sumber. Terjemahan oleh Susi Septaviana. Bandung: Universitas Pendidikan Indonesia (UPI). 